\title{
Dampak COVID19 Pada Kesiapan Teknologi dan Penerimaan Teknologi di Kampus
}

\author{
Rorim Panday \\ Fakultas Ekonomi dan Bisnis; Universitas Bhayangkara Jakarta Raya; Jl. Raya \\ Perjuangan, Marga Mulya, Bekasi Utara, Jawa Barat 17121. Telp: 021-88955882, 889955883; \\ e-mail: indripan@gmail.com \\ * Korespondensi: e-mail: indripan@gmail.com
}

\begin{abstract}
Covid-19 is currently in Indonesia for more than 5 months. To prevent this disease becoming widespread, various strategies have been carried out, among others, by doing Lock Down and large-scale social restrictions. Community activities are affected. By relying on communication technology and IT including the Internet, people can still do activities even with limitations. Likewise, Higher Education got limited activities. For this reason, all teaching and learning activities used an online system known as e-learning. This paper conveys various activities on campus and its constraints during the covid-19. In general, the constraints aside from technological facilities are also obstacles from the academic community in matters relating to technology readiness and technology acceptance, which are delivered descriptively.
\end{abstract}

Keywords: Covid19, e-learning, technology readiness, technology acceptance

\begin{abstract}
Abstrak
Covid-19 tengah melanda Indonesia saat Ini sudah 5 bulan lebih. Untuk mencegah wabah ini menjadi luas maka dilakukan berbagai strategi antara lain dengan melakukan Lock Down dan pembatasan social skala besar. Kegiatan masyarakat menjadi terpengaruh. Dengan mengandalkan teknologi komunikasi dan IT diantaranya Internet, masyarakat masih dapat melakukan Kegiatan walaupun dengan keterbatasan. Demikian juga dengan Perguruan tinggi, mengalami keterbatasan kegiatan. Untuk itu segala Kegiatan belajar mengajar menggunakan system daring yang dikenal dengan e-learning. Makalah ini menyampaikan macam-macam kegiatan di kampus dan kendalanya dalam masa covid-19. Secara umum kendalanya selain fasilitas teknologi juga kendala dari civitas akademika dalam hal yang terkait dengan kesiapan teknologi dan penerimaan teknologi, yang disampaikan secara diskriptif.
\end{abstract}

Kata kunci: Covid19, e-learning, kesiapan teknologi, penerimaan teknologi

\section{Pendahuluan}

Covid-19 telah menjadi wabah melanda dan menyebar hampir diseluruh dunia, yang mana pertama kali terjadi di Wuhan China. Penyakit ini adalah berupa virus yang bisa mematikan manusia dalam hitungan hari apabila tidak dilakukan penanganan, pencegahan ataupun pengobatan. Penyakit ini mudah tersebar apabila terjadi infeksi yang cukup dekat antara sesorang dengan orang yang telah terkena virus ini melalui bersentuhan misalnya dengan berjabat tangan, atau menular melalui udara, melalui pernafas.

Oleh karena itu munculah protokol kesehatan: jaga jarak, gunakan masker, dan mencuci tangan, hindari kerumunan/ keramaian. Dan sebagai kelanjutan muncullah aturan pembatasan kegiatan sosial berskala besar (PSBB). Salah satu strategi yang paling umum 
dalam meminimasi dampak kesehatan karena Covid-19 adalah melakukan lockdown, artinya kegiatan dari suatu wilayah dihentikan dengan cara penduduknya tinggal dirumah, bekerja dirumah, beribadah dirumah.

Sebagai dampak dari protokol kesehatan, pembatasan kegiatan social berskala besar dan lockdown, maka berbagai kegiatam umum di hentikan seperti: kegiatan perkantoran umum dan swasta, kegiatan pendidikan untuk berbagai jenjang pendidikan, kegiatan pabrik, kegiatan tranportasi, kegiatan pusat perbelanjaan, dan berbagai kegiatan ekonomi lainnya.

Namun demikian, kegiatan-kegiatan tersebut sedapat mungkin untuk dapat berjalan, salah satunya dengan menggunakan berbagai teknologi komunikasi dan teknologi digital.

Satu hal yang disyukuri, dengan adanya kondisi seperti itu, perkembangan teknologi komunikasi dan teknologi digital sudah berkembang dengan cukup baik seperti: information technology (IT) (internet dan perangkatnya dan unsur penunjangnya).

Dengan adanya perkembangan teknologi tersebut, maka banyak hal dari kegiatan masih dapat berjalan. Dengan adanya kondisi ini, maka masyarakat/penduduk, mau tidak mau harus menggunakan teknologi komunikasi ini agar kegiatan yang mereka lakukan dapat berjalan.

Untuk dapat menggunakan teknologi tersebut mau tidak mau mereka belajar dengan cepat, tapi ada juga yang lambat. Gaya hidup dan cara kerja masing-masing orang menjadi berubah dengan adanya wabah Covid-19.

Dari sesorang yang tidak pernah menggunakan teknologi, yang gagap teknologi, dengan adanya Covid19, mereka jadi bisa menggunakan teknologi dan percaya dengan teknologi, contohnya percaya dengan transfer uang menggunakan e-mobile banking, membayar dengan e-money, membayar dengan go-pay, dan sebagainya, bahkan menjadi sangat percaya dengan berbinis secara e-commerce. Sehingga dari seseorang yang tidak siap berteknologi (No Technology readiness), menjadi siap berteknologi, dari yang tidak menerima teknologi (No Technology acceptance), menjadi menerima teknologi.

Semua itu terjadi karena situasi yang memaksa, mau tidak mau harus siap dan menerima teknologi dan bersatu dengan teknologi.

\section{Metode Penelitian}

\subsection{Kesiapan Teknologi (Technology Readiness)}

Kesiapan teknologi (TR: Rechnology Readiness) mengacu pada "kecenderungan orang untuk merangkul dan menggunakan teknologi baru untuk mencapai tujuan dalam kehidupan rumah dan di tempat kerja"(Parasuraman, 2000), yang dapat dilihat dari empat dimensi kepribadian: optimism, innovativeness, discomfort, and insecurity.

Menurut (Parasuraman, 2000) dimensi kepribadian ini mempengaruhi kecenderungan orang untuk merangkul dan menggunakan teknologi baru.

Dalam hal ini fungsi optimism dan innovativeness sebagai enabler mental, sedangkan fungsi discomfort dan insecurity sebagai penghambat mental untuk menerima teknologi baru. 
TR adalah kombinasi dari keyakinan terkait teknologi yang positif dan negatif. Keyakinan ini diasumsikan bervariasi di antara individu. Secara kolektif, keyakinan yang ada bersama ini menentukan kecenderungan seseorang untuk berinteraksi dengan teknologi baru (Parasuraman, A., \& Colby, 2001). Empat dimensi TR adalah (Parasuraman, 2000):

1) Optimism didefinisikan sebagai "pandangan positif tentang teknologi dan keyakinan yang menawarkan peningkatan kontrol, fleksibilitas, dan efisiensi kepada orang-orang dalam kehidupan mereka"(Parasuraman, A., \& Colby, 2001). Secara umum menangkap perasaan positif tentang teknologi.

2) Innovativeness didefinisikan sebagai "kecenderungan untuk menjadi pelopor teknologi dan pemimpin pemikiran" [9]. Dimensi ini umumnya mengukur sejauh mana individu memandang diri mereka sebagai yang terdepan.

3) Discomfort didefinisikan sebagai "kurangnya kontrol atas teknologi dan perasaan kewalahan olehnya"(Parasuraman, A., \& Colby, 2001). Dimensi ini umumnya mengukur ketakutan dan kekhawatiran yang dialami orang ketika dihadapkan dengan teknologi.

4) Insecurity didefinisikan sebagai "ketidakpercayaan terhadap teknologi dan skeptisisme tentang kemampuannya untuk bekerja dengan baik"(Parasuraman, A., \& Colby, 2001). Dimensi ini berfokus pada kekhawatiran yang mungkin orang miliki dalam menghadapi transaksi berbasis teknologi. Optimisme dan inovasi adalah pendorong kesiapan teknologi. Skor tinggi pada dimensi ini akan meningkatkan kesiapan teknologi secara keseluruhan.

Di sisi lain, ketidaknyamanan dan rasa tidak aman adalah penghambat kesiapan teknologi. Dengan demikian, skor tinggi pada dimensi ini akan mengurangi kesiapan teknologi secara keseluruhan. Hasil penelitian menunjukkan bahwa empat dimensi cukup independen, masing-masing memberikan kontribusi unik terhadap kesiapan teknologi individu (Parasuraman, A., \& Colby, 2001).

\subsection{Penerimaan Teknologi (Techology Acceptance)}

Teori lain yang digunakan dalam artikel ini adalah model penerimaan teknologi (TAM), yang diperkenalkan oleh (Davis, 1989); Dalam TAM ada dua faktor penentu utama: Manfaat yang dirasakan, yang merujuk pada "sejauh mana seseorang percaya bahwa menggunakan sistem tertentu akan meningkatkan kinerja pekerjaannya"(Davis, 1989); dan persepsi kemudahan penggunaan, yang mengacu pada "sejauh mana seseorang percaya bahwa menggunakan sistem tertentu akan bebas dari upaya"(Davis, 1989).

TAM dirancang khusus untuk menjelaskan perilaku penggunaan komputer. Ini adalah adaptasi dari Fishbein dan Azjen (Fishbein, M., \& Ajzen, 1975) dalam teori tindakan yang beralasan (TRA), yang telah berhasil memprediksi dan menjelaskan perilaku secara umum (Yi \& Hwang, 2003)(Malhotra, Y., \& Galletta, 1999)(Malhotra, Y., \& Galletta, 1999). TAM telah menerima banyak dukungan selama bertahun-tahun. Ini telah divalidasi melalui berbagai sistem, dan manfaat yang dirasakan dan kemudahan penggunaan yang dirasakan telah terbukti dimensi kognitif yang andal dan valid (King, W. R., \& He, 2006) (Burton-jones \& Hubona, 2006). 
Dalam artikel ini digunakan TRI terintegrasi dengan TAM, yang "kecenderungan orang untuk merangkul dan menggunakan teknologi baru untuk mencapai tujuan dalam kehidupan rumah dan di tempat kerja" yang terkait dengan penerimaan teknologi. Model terintegrasi ini bernama TRAM (Technology Readiness-Acceptance Model). Model terintegrasi ini telah digunakan oleh beberapa peneliti seperti (Lin, C.-H., Shih, H.-Y., Sher, 2005), and (Walczuch, Lemmink, \& Streukens, 2007).

Peneliti lain yang juga menggunakan TRAM adalah: a) Murat Esen, Nihat Erdogmu (Murat Esen, 2014) , melakukan penelitian mereka tentang efek kesiapan teknologi pada penerimaan teknologi dalam e-HRM. b) Kuang-Ming Kuo, Chung-Feng Liu and Chen-Chung Ma (Kuo, Liu, \& Ma, 2013), melakukan penelitian mereka untuk menyelidiki pengaruh kesiapan teknologi perawat pada penerimaan sistem rekam medis elektronik bergerak. c) Mimin Nur Aisyah, Mahendra Adhi Nugroho, Endra Murti Sagoro (Mimin Nur Aisyah, Mahendra Adhi Nugroho, 2013), melakukan penelitian mereka tentang pengaruh kesiapan teknologi terhadap penerimaan teknologi di UMKM di Yogyakarta. d) Anders Husa, Magnus Kvale (Kvale \& Husa, 2009) melakukan penelitian mereka tentang kerangka kerja TRAM dalam konteks media sosial dengan mengukur sikap terhadap interaksi konsumen-perusahaan, sebagai studi terhadap pengguna media sosial Norwegia. e) Rita Walczuch, Jos Lemmink, Sandra Streukens (Walczuch et al., 2007), melakukan penelitian mereka tentang pengaruh kesiapan teknologi layanan karyawan pada penerimaan teknologi. f) Issham Ismail, Siti F Bokhare, Siti N Azizan, Nizuwan Azman (Ismail, Bokhare, Azizan, \& Azman, 2013), melakukan penelitian tentang pengajaran melalui ponsel, sebagai studi kasus tentang Penerimaan dan Kesiapan Teknologi guru Malaysia. g) Jui-yen Yen. (Yen \& Chen, 2010), melakukan penelitian perspektif dari model TRAM tentang adopsi e-Learning, sebagai analisis industri rantai dan waralaba di Taiwan. h) Nadine Guhr, Tai Loi, Rouven Wiegard, and Michael H. Breitner (Guhr, Loi, Wiegard, \& Breitner, 2013), melakukan penelitian tentang kesiapan teknologi dalam persepsi pelanggan dan penerimaan pembayaran mobile sebagai studi empiris di Finlandia, Jerman, Amerika Serikat dan Jepang. i) Rorim Panday (Panday, 2015c) melakukan penelitian tentang Pengaruh Kesiapan Teknologi terhadap Penerimaan Teknologi dalam Penggunaan Layanan Sistem Informasi Akademik. j) Rorim Panday (Panday, 2015a), use TRAM pada siswa geodesi dalam menggunakan ina geoportal, k) Rorim Panday (Panday, 2015b), Use TRAM pada kegiatan manajemen proyek. Dalam pembahasan beberapa fenomena yang terkait dengan kesiapan teknologi dan penerimaan teknologi dimasa Covid-19 di kampus.

\section{Hasil dan Pembahasan}

\subsection{Bidang Pendidikan}

Pendidikan, semula dilaksanakan dengan cara tatap muka dikelas, dimana guru atau dosen memberikan pelajaran / kuliah di ruang kelas. Dengan adanya covid-19, telah merubah metode belajar mengajar, menggunakan apa yang telah dikenal sebelum adanya covid-19 
dengan e-learning. E-learning sebelum adanya covid-19 hanya terbatas pada beberapa sekolah dan perguruan tinggi, karena keterbatasan sarana dan prasarana.

Dengan adanya covid-19 yang memaksa Perguruan tinggi/sekolah melakukan pembelajaran dengan cara e-learning. Mengadakan sarana dan prasarana untuk melaksanakan e-learning, dengan paling tidak memenuhi syarat minimum untuk dapat terlaksananya elearning, walaupun belum fully e-learning. Ternyata dalam pelaksanaannya, ada berbagai cara dosen dalam melaksanakan pembelajaran dengan e-learning.

Hal ini terjadi karena keterbatasan dosen dalam memahami apa itu e-learning, bagaimana melaksanakannya, serta keterbatasan penguasaan teknologi yang digunakan pada pelaksanaan e-learning. Berikut ini adalah beberapa macam e-learning yang dilaksanakan oleh dosen.

1) Ada Dosen yang membuat bahan kuliah dan satu atau dua soal latihan untuk satu pertemuan dalam file word atau bahkan dalam bentuk power Point. Kemudian bahan kuliah tersebut di share kepada mahasiswa melalui whatsapp dan diberikan perintah belajar melalui whatsapp.

Tidak ada interaksi antara dosen dan mahasiswa, hanya satu arah saja. Dari sekian banyak mahasiswa yang mengambil mata kuliah tersebut, hanya beberapa saja yang bertanya tentang bahan matakuliah yang diberikan oleh dosen, untuk mendapatkan kejelasan dari bahan kuliah tersebut.

Selanjutnya hasil pekerjaan latihan oleh mahasiswa dikirim ke dosen melalui email dosen.

2) Dosen yang membuat bahan kuliah dan satu atau dua soal latihan untuk satu pertemuan dalam file word atau bahkan dalam bentuk power Point dan video presentasi bahan kuliah.

Kemudian bahan kuliah tersebut di share kepada mahasiswa melalui whatsapp, untuk video diberi link dari video tersebut dan diberikan perintah belajar melalui whatsapp. Ada interaksi melalui whatsapp.

Selanjutnya hasil pekerjaan latihan oleh mahasiswa dikirim ke dosen melalui email dosen.

3) Ada Dosen yang membuat bahan kuliah dan satu atau dua soal latihan untuk satu pertemuan dalam file word atau bahkan dalam bentuk power Point. Kemudian bahan kuliah tersebut di share kepada mahasiswa melalui system e-learning dan diberikan perintah belajar melalui e-learning.

Tidak ada interaksi antara dosen dan mahasiswa, hanya satu arah saja. Dari sekian banyak mahasiswa yang mengambil mata kuliah tersebut, hanya beberapa saja yang bertanya tentang bahan matakuliah yang diberikan oleh dosen, untuk mendapatkan kejelasan dari bahan kuliah tersebut melalui whatsapp.

Selanjutnya hasil pekerjaan latihan oleh mahasiswa dikirim ke dosen melalui email dosen. Jadi system e-learning hanya untuk mengupload bahan kuliah saja. 
4) Ada Dosen yang membuat bahan kuliah dan satu atau dua soal latihan untuk satu pertemuan dalam file word atau bahkan dalam bentuk power Point. Kemudian bahan kuliah tersebut di share kepada mahasiswa melalui system e-learning dan diberikan perintah belajar melalui e-learning.

Tidak ada interaksi antara dosen dan mahasiswa, hanya satu arah saja. Dari sekian banyak mahasiswa yang mengambil mata kuliah tersebut, hanya beberapa saja yang bertanya tentang bahan matakuliah yang diberikan oleh dosen, untuk mendapatkan kejelasan dari bahan kuliah tersebut melalui whatsapp.

Selanjutnya hasil pekerjaan latihan oleh mahasiswa dikirim ke dosen melalui e-learning dosen. Sudah lebih menggunakan e-learning namun interaksi masih melalui whatsapp.

5) Ada Dosen yang membuat bahan kuliah dan satu atau dua soal latihan untuk satu pertemuan dalam file word atau bahkan dalam bentuk power Point. Kemudian bahan kuliah tersebut di share kepada mahasiswa melalui system e-learning dan diberikan perintah belajar melalui e-learning.

Tidak ada interaksi antara dosen dan mahasiswa, hanya satu arah saja. Dari sekian banyak mahasiswa yang mengambil mata kuliah tersebut, hanya beberapa saja yang bertanya tentang bahan matakuliah yang diberikan oleh dosen, untuk mendapatkan kejelasan dari bahan kuliah tersebut melalui e-learning. Selanjutnya hasil pekerjaan latihan oleh mahasiswa dikirim ke dosen melalui e-learning dosen.

6) Ada Dosen yang membuat bahan kuliah dan satu atau dua soal latihan untuk satu pertemuan dalam file word atau bahkan dalam bentuk power Point dan Video presentasi bahan kuliah. Kemudian bahan kuliah dan link video tersebut di share kepada mahasiswa melalui system e-learning dan diberikan perintah belajar melalui e-learning. Ada interaksi antara dosen dan mahasiswa, melalui system e-learning yang tersedia.

Mahasiswa yang mengambil mata kuliah tersebut yang bertanya tentang bahan matakuliah yang diberikan oleh dosen, untuk mendapatkan kejelasan dari bahan kuliah tersebut melalui e-learning. Selanjutnya hasil pekerjaan latihan oleh mahasiswa dikirim ke dosen melalui e-learning dosen.

7) Ada juga dosen yang melakukan dengan cara 6), namun video presentasi diganti dengan tatap muka melalui teleconference facility yaitu program Zoom atau google meet.

Dari 7 macam penyampaian perkuliahan, bahwa dosen maupun mahasiswa memiliki kesiapan teknologi dan penerimaan teknologi yang beragam, serta pemahanan tentang elearning yang beragam.

Dalam mengerjakan soal latihan, terindikasi Mahasiswa masih bisa ber 'komunikasi' satu dengan lainnya untuk membuat jawaban atau penyelesaian soal latihan. Disela-sela perkuliahan e-learning, pihak universitas, dalam hal ini bagian IT team, mengadakan "Talk learning and sharing" setiap hari Senin. Namun demikian dosen yang bisa bergabung pada sesi ini hanya sebagian saja. 
Padahal diadakan sesi tersebut adalah untuk menambahan pengetahuan dosen dalam menggunakan system e-learning yang tersedia. Walaupun sudah 9 kali lebih mengadakan sesi sharing ini, fenomena 7 pelaksanaan e-learning masih tetap berjalan.

Dari hal ini mengindikasi bahwa kesiapan teknologi dan penerimaan teknologi dosen terutama untuk e-learning masih kurang dari yang diharapkan.

\subsection{Ujian Tengah Semester}

Selain perkuliahan, pelaksanaan Ujian Tengah semester, dilaksanakan dengan menggunakan system e-learning yang tersedia, yaitu dosen mengupload soal UTS, mahasiswa masuk ke system e-learning, melakukan absensi, mahasiswa mengunduh soal UTS, kemudian mengerjakan soal ujian dan hasilnya di upload lagi menggunakan system e-learning, dosen mengunduh hasil kerja Mahasiswa dari e-learning, kemudian memasukkan nilai ke system informasi akademik dan memindahkan absensi mahasiswa yang ada di e-learning ke system informasi akademik.

Dalam mengerjakan soal UTS, terindikasi Mahasiswa masih bisa ber 'komunikasi' satu dengan lainnya untuk membuat jawaban atau penyelesaian soal, sehingga jawaban beberapa mahasiswa ada yang sama persis.

\subsection{Ujian Proposal Tugas akhir Mahasiswa}

Hal lain Dalam penggunaan teknologi semasa covid19 dikampus adalah melaksanakan ujian proposal Tugas Akhir mahasiswa. Pelaksanaan ujian ini dilakukan dengan menggunakan Tele-conference dengan fasilitas Zoom yang 'gratisan'.

Sebelum pelaksanaan ujian proposal, disusun terlebih dahulu Jadwal ujiannya, yaitu nama mahasiswanya, dosen pembimbing, dosen penguji, jam pelaksanaan, lamanya ujian, dan siapa yang menjadi hostnya yang bertindak sebagai moderator.

Pelaksanaan ujian untuk masing-masing Mahasiswa adalah 30 menit, 15 menit untuk presentasi mahasiswa dan 15 menit berikutnya untuk tanya jawab dosen terhadap mahasiswa. Karena masih menggunakan fasilitas Zoom yang gratisan, maka setiap 1 jam dilakukan connecting zoom yang baru lagi dan menginvite dosen dan mahasiswa.

Dalam pelaksanaan ujian proposal ini, masih ada dosen yang belum begitu paham dalam menggunakan aplikasi zoom, sehingga dalam pelaksanaannya masih harus di supervise.

\subsection{Rapat Dosen}

Untuk rapat Dosen dilakukan pada masa covid19 dengan menggunakan fasilitas Zoom yang gratisan.

Dalam hal ini pihak fakultas sebagai host meng invite dosen untuk bergabung, melalui whatsapp. Dalam hal ini rapat dosen terbatas oleh waktu zoom yang gratisan tersebut, apabila 
rapat belum selesai, terpaksa harus melakukan connecting baru dan dosen diminta untuk bergabung kembali.

Dalam pelaksanaannya, ada banyak dosen yang menggunakan zoom memakai laptop dan ada beberapa yang menggunakan handphone. Pada penggunaan zoom, masih ada beberapa dosen yang belum begitu mahir dalam menggunakannya.

\subsection{Pelatihan dan Seminar}

Penulis dengan beberapa teman dosen mengadakan pelatihan menggunakan Zoom. Pelatihan yang diadakan adalah pelatihan gratis, bagaimana menggunakan program SPSS untuk analisa Multiple regresi. Sebelum pelaksanaan, dilakukan promosi melalui medsos untuk kalangan mahasiswa yang sedang melaksanakan tugas akhir.

Dalam pelaksanaan pelatihan ini, juga terbatas waktu Penggunaan zoom nya, karena menggunakan fasilitas zoom yang gratis, sehingga di tengah-tengah pelaksanaan, harus melakukan connecting dan invite lagi terhadap para peserta.

\section{Kesimpulan}

Dari uraian di atas maka dapat disimpulkan sebagai berikut: a) Situasi Covid19 memberi dampak yang memaksa para dosen dan mahasiwa harus menggunakan teknologi dalam kegiatan belajar mengajar. b). Fasilitas e-learning kampus masih perlu peningkatan agar dosen dapat lebih mudah lagi dalam menggunakannya, dan meningkatkan kapasitas IT nya. c) Masih ada dosen yang belum siap menggunakan teknologi dan menerima teknologi, d) Perlu adanya pembelajaran atau pelatihan online bagi dosen untuk lebih baik lagi menggunakan system e-learning yang tersedia dan meningkatkan konten dari e-learning itu sendiri. e) Tulisan ini perlu ditindaklanjuti dengan penelitian sesuai judulnya.

\section{Daftar Pustaka}

Burton-jones, A., \& Hubona, G. S. (2006). The mediation of external variables in the technology acceptance model, 43, 706-717. https://doi.org/10.1016/j.im.2006.03.007

Davis, F. D. (1989). Perceived usefulness, perceived ease of use, and user acceptance of information technology. MIS Quarterly, 13, 319-340. https://doi.org/10.2307/249008

Fishbein, M., \& Ajzen, I. (1975). Belief, attitude, intention, and behavior: An introduction to theory and research. Reading,.

Guhr, N., Loi, T., Wiegard, R., \& Breitner, M. H. (2013). Technology Readiness in Customers ' Perception and Acceptance of M ( obile ) -Payment: An Empirical Study in Finland, Germany, the USA and Japan, (March), 119-133.

Ismail, I., Bokhare, S. F., Azizan, S. N., \& Azman, N. (2013). Teaching via mobile phone: A case study on Malaysian teachers' technology acceptance and readiness. Journal of Educators Online, 10(1), 1-38. https://doi.org/10.9743/JEO.2013.1.3 
King, W. R., \& He, J. (2006). A meta-analysis of the technology acceptance model. https://doi.org/10.1016/j.im.2006.05.003

Kuo, K. M., Liu, C. F., \& Ma, C. C. (2013). An investigation of the effect of nurses' technology readiness on the acceptance of mobile electronic medical record systems. BMC Medical Informatics and Decision Making, 13(1), 1. https://doi.org/10.1186/1472-6947-13-88

Kvale, M., \& Husa, A. (2009). The TRAM Framework in a Social Media Context - Measuring Attitudes Towards Consumer-Company Interaction. BI Master Thesis, 1-77.

Lin, C.-H., Shih, H.-Y., Sher, P. J. . W. Y.-L. (2005). Consumer adoption of e-service: Integrating technology readiness with the technology acceptance model. In Proceedings of PICMET '05: Technology Management: A Unifying Discipline for Melting the Boundaries (pp. 483488). Portland, Oregon, USA. https://doi.org/10.1109/PICMET.2005.1509728

Malhotra, Y., \& Galletta, D. F. (1999). Extending the technology acceptance model to account for social influence: Theoretical bases and empirical validation. In . Proceedings of the 32nd Hawaii International Conference on System Sciences, Maui, Hawaii, USA, 114. https://doi.org/10.1109/HICSS.1999.772658

Mimin Nur Aisyah, Mahendra Adhi Nugroho, E. M. S. (2013). Pengaruh Technology Readiness Terhadap Penerimaan Teknologi komputer Pada UMKM di Yogyakarta.

Murat Esen, N. E. (2014). Effects of Technology Readiness On Technology Acceptance In EHRM: Mediating Role of Perceived Usefulness. Retrieved from http://www.beykon.org/dergi/ 2014/SPRING/M.Esen.pdf

Panday, R. (2015a). Analysis of technology readiness and technology acceptance of geodesy student in using ina geoportal, (November), 10-12.

Panday, R. (2015b). Evaluation of Technology Readiness-Acceptance in Operation of Project Management Services. Banda Aceh, Indonesia: Presenting and publishing in proceeding, at 1st Joint Conference Indonesia Malaysia, Bangladesh and Ireand at Ubudiyah Indonesia University.

Panday, R. (2015c). The Effect of Technology Readiness on Technology Acceptance in Using Services Delivery of Academic Information System (pp. 978-979).

Parasuraman, A., \& Colby, C. L. (2001). Techno-ready marketing: How and why your customers adopt technology. New York: Free Press.

Parasuraman, A. (2000). Technology readiness index (TRI): A multiple-item scale to measure readiness to embrace new technologies. Journal of Service Research, 2. https://doi.org/10.1177/109467050024001

Walczuch, R., Lemmink, J., \& Streukens, S. (2007). The effect of service employees technology readiness on technology acceptance $\S, 44,206-215$. https://doi.org/10.1016/j.im.2006.12.005

Yen, J., \& Chen, S. (2010). Perspectives from the TRAM Model on Adopting e-Learning: An Analysis of the Chain and Franchise Industry in Taiwan. 北商學報 第.

Yi, M. Y., \& Hwang, Y. (2003). Predicting the use of web-based information systems: Self- 
Rorim Panday

Submitted: 20 Juni 2020; Revised: 11 Juli 2020; Accepted: 30 Juli 2020; Published: 31 Juli 2020

efficacy, enjoyment, learning goal orientation, and the technology acceptance model. International Journal of Human Computer Studies. https://doi.org/10.1016/S10715819(03)00114-9 